\title{
TITLE:
}

\section{COMPOSITION OF THE FIXED SEA URCHIN COLONY ON HATAKEZIMA ISLAND, 1976}

\section{$\operatorname{AUTHOR}(\mathrm{S}):$}

Tokioka, Takasi; Imafuku, Michio

\section{CITATION:}

Tokioka, Takasi ... [et al]. COMPOSITION OF THE FIXED SEA URCHIN COLONY ON HATAKEZIMA ISLAND, 1976. PUBLICATIONS OF THE SETO MARINE BIOLOGICAL LABORATORY 1977, 23(6): 425-426

ISSUE DATE:

1977-03-25

URL:

http://hdl.handle.net/2433/175945

RIGHT: 


\section{COMPOSITION OF THE FIXED SEA URCHIN COLONY ON HATAKEZIMA ISLAND, 1976}

The regular observation was made on May 14, 1976 around noon, when it was fine and a breeze came from the northwest. The water was lowest, $-11 \mathrm{~cm}$, at 12:04. The harvest of Hizikia fusiforme Okamura was over and the area around the fixed colony was wholly exposed. The rocky shore and the east half of the sandy beach on the southern side of the reef region of the island were found heavily affected by silt sedimentation and the fauna and flora were greatly damaged there by this. Very probably this was caused by the inflow from the west of silt dredged up carelessly in the season of the monsoon from the northwest in the camber at Ezura just near the entrance to the passage between the island and the land. The west, north and east sides of the reef region and the island were free from such sedimentation.

The ratio of the number of Echinostrephus to that of Anthocidaris (E/A) was 1.981, this was seemingly dependent on a slight decrease of Anthocidaris in the colony.

\begin{tabular}{lrrrrrr}
\hline \hline May 14, 1976 & I (SW) & II (NW) & III (SE) & IV (NE) & total & $\%$ \\
\hline Anthocidaris crassispina & 43 & 41 & 75 & 48 & 207 & 30.9 \\
Echinostrephus aciculatus & 61 & 177 & 91 & 81 & 410 & 61.3 \\
Echinometra mathaei & 8 & 12 & 8 & 24 & 52 & 7.8 \\
\hline \multicolumn{1}{c}{ Total } & & & & & 669
\end{tabular}

As it had been noticed that oysters and some mussels on the island were much decreased last summer, special notices were paid to the states of such shells at this and subsequent visits to the island. And recently, it was concluded that Saxostrea echinata (Quoy et Gaimard), Adula atrata (Lischke), Septifer bilocularis (Linné), Septifer (Mytilisepta) virgatus (Wiegmann), Modiolus agripetus (Iredale) and Hormomya mutabilis (Gould) were completely or nearly perished on the shore all around the island. Evidently this was not related with the silt sedimentation referred to above, as the drastic decrease had started prior to this and the eradication of these shells extended to the west-northeast sides of the reef region and the island, that were quite free from sedimentation. As Barbatia (Savignyarca) virescens (Reeve) of Arcidae is still alive rather richly on the shore, it is supposed if only the shells of Mytilidae and Ostreidae have been damaged. As these shells are all living as usual around the rocky reef of Tosima Islet, about $1.5 \mathrm{~km}$ west of Hatakezima Island, the damage seems to be quite local. Of the perished mussels, the distribution of Hormomya mutabilis on the island was ever closely checked and recorded in 1972, when it was the most-dominant bivalve on the island, 
occurring very densely nearly all around the island and the reef region near the low water mark of the rocky shore (Senawong, C.: Biological studies of a littoral mussel, Hormomya mutabilis (Gould) III. Publ. Seto Mar. Biol. Lab., XIX (5), 269-291). The complete disappearance of live Saxostrea and Modiolus from the island is the first event to all of the laboratory.

It is very difficult to explain this phenomenon, though it is not impossible that the outbreak of some microbe very noxious to mussels and oysters like protozoan MSX or fungus Dermocystidium marinum concerned the damage and the outbreak itself might be allowed in the waters of the area contaminated over a certain level by domestic sewage and the waste of the net-cage fishery extensively carried out in the area.

Only Adula atrata has been found somewhat recovered this summer on the island, but at the sites different from the former places. And on the other hand, a neritid snail, Theliostyla albicilla (Linné), seems to have increased markedly around the island and also along the shore around the tip of the Cape Bansyozaki since last summer.

TAKAsi TOKIOKA and MichIo IMAFUKU 